\title{
Interactive Learning in the Medical English Classroom
}

\author{
Sharipova Feruza*, Akhmedova Aziza, Jalilova Nilufar \\ Department of Foreign Languages Teacher, Tashkent Pediatric Medical Institute, Uzbekistan
}

Received February 24, 2020; Revised March 23, 2020; Accepted March 28, 2020

\begin{abstract}
Copyright $@ 2020$ by authors, all rights reserved. Authors agree that this article remains permanently open access under
\end{abstract} the terms of the Creative Commons Attribution License 4.0 International License

\begin{abstract}
The knowledge of English language is increasingly important in the world today. English language is one of the essential components of modern education, and is part of the curricula of all study programs in all medical institutes of the Republic of Uzbekistan. This study covers a short overview of medical English language teaching in the Tashkent Pediatrician Medical Institute, highlights problems of teaching English in the medical institutes and suggestions for solution. The aim of this paper is to teach English language with interactive learning facilitates by display graphic organizers and role-play games alongside the study of English language, showing the main items of study information and controlling the study material by estimation and assessment methods. As predicted, providing interactive learning on English language lessons improved students' motivation and increased a rate of attendance English classes. Also there was research on future specialty workplaces, in particular medical foreign organizations, where knowledge and practice of English language is mostly required. The responses of HR department of these organizations' interviews was given in this paper as diagram scheme, resulting in poor basic speaking skills of English language among young medical specialists. The material and methods of this paper are analyzing the collected material, and methods of analysis and synthesis were used.
\end{abstract}

Keywords Teaching, Professional English Language, First-Course Students, Graphic Organizers, Future Medical Workplace

\section{Introduction}

We live in a busy world where English language plays a great important role in professional development of social human being. English language actively is used as basic one in Internet web-sites, smart-phones and social networks such as Facebook, Odnoklassniki or other social groups that greatly influence on internal of the person and external world in very rapid rate. Nowadays students have different backstage and levels of English language due to these modern trends of internet communication. Students also have various and multiple ideas in their minds about using English language in their future profession as doctors of general practice. And when teacher starts to teach in the classroom, students expect from teacher how to learn, to work with the received information from outside such as Internet resources and social media in their future profession. How teacher can do this with so different levels of English language proficiency?

The term "interactive learning" is not only meant apps of gadgets and mobile phones, but also it can be used without them by implying graphic schemes or live dialogue with real partners. Interactive learning technologies without computer is more efficient and means collective cognitive activity where all participants interact, exchange information, solve problems in atmosphere of real collaboration, estimate their own actions [1].

The problem of interactive learning at the colleges and universities was also studied by R. Blair [2], S. Martinelli [3], H. Stern [4], E. Polat [5], M. Tailor [6] and others.

Warschauer [7] proposed two different ways to integrate technology into the class: a cognitive approach which gives learners the opportunity to meaningfully increase their exposure to language and thus make their own knowledge; and a social approach which gives learners opportunities for authentic social interactions as a means to practice the real-life skills obtained through engagement in real activities. Thus, interactive technology comprises a scope of interactive methods that a teacher uses in his work. Modern methodology defines method as a way to reach a goal. There are different points of view at the classification of interactive learning methods. For example, Salaberry group interactive methods into discussions, games and trainings [8]. Graphic organizers which are specifically designed for facilitating learning and instruction of the context are visual and spatial symbols which describe content, structure and the key conceptual relationships of the text using lines, arrows and circles [9]. Graphic organizers are tools which combine linguistic forms like words and phrases with non-linguistic forms like symbols and arrows which show relationships [10]. The basis of interactive learning is a direct dialogue student -student by using role-play games or graphic organizers. These 
technologies reflect the main features of interactive methods of teaching foreign languages: activity, collectivity and situational training activities; developing students' reflective skills, attention, imagination, observation, innovative thinking; educational consistency, logic, critical thinking and creativity, efficiency, curiosity, cognitive independence and persistence in achieving goals.

As teachers of English language in the Tashkent Pediatric Medical Institute, we have concerns specifically related to professional (medical) English language. The teaching of foreign languages at the Tashkent Pediatrician Medical Institute was launched in the academic year 1972 as we can see in the official web-site [11]

The course of English language was entered as a basic one in the first, second and third year of the study in practically all faculties of the Tashkent Pediatrician Medical Institute. The methodology of English language consists of practical lessons and includes 114 hours of each year. During the course students study basic grammar, medical lexicology, listen to audio dialogues of doctor and patient, write down thesis paper in English on their future medical specification on the third course. Medical textbooks, guide-books, encyclopedias, research and professional articles in PDF format as the irreplaceable tools can be found out in many medical research web sites. The presentation papers that are submitted at the end of each year has multiple functions such as searching information in Internet resources, writing this material without mistakes, and last one, orally speaking presentation paper, working out pronunciation and orator skills. But the main focus of such presentation papers is medical topic, which the student chooses. Here we can see integration of medicine and study of English language, establishment of correlation with the passed materials that have been studied during each year with the following text-books of following authors: A.M. Maslova, Z.I. Wainstein, L.S. Plebeyskaya, L.U.Khojayeva L.U., Arziyeva D.T. and others [12,13]. Because of the function of transmission of the text and words form above-mentioned text-books to the graphic organizers, team and role-pay games in the classroom, interactive learning can make the teaching process more direct, active, rapid and convenient so that it can be widely used in non-lingual universities by English teachers and become more and more popular among students. Also we can note a personal experience of student and its interpretation of Medical English in his presentation papers. However, to reach the above-mentioned aims of the curriculum of our institute we have faced with some of problems at first-year students in teaching Medical English Language, there are some disadvantages in using interactive learning methods in English classroom. For example, overloading too much information without any necessary and personal instructions for students, some students have not sufficient English language background for starting university level and can't elaborate the simple points very well, even all non-lingual universities in Uzbekistan have English language exam as entrance one, some students can't understand very well because of the fast speed and a huge volume of test tasks at the starting course in the university. How to make a good use of interactive learning to improve English teaching and learning? Some basic principles and methods should be noted in English teaching process. Most of these problems of psychological and personal character can be easily decided by interactive technique of teaching technologies [14]. To relax and calm down the nervous and intense atmosphere at first lessons of Medical English Language, we need mastership and great experience of the teachers of our institute.

There are different sensations as fear, anxiety, and impatience and nervous intense often presented at the beginning of English lesson. There are so many excellent activities for starting the lesson and calming down some anxious students or in contrary to motivate quiet students, Research has shown that negatives emotions or sensations can effect on classroom environment. "Low anxiety appears to be conductive to second language acquisition, whether measured as personal or classroom anxiety". How can we eliminate these aggressive or negative quiet emotions? Interactive methods as excellent activities overcome intense atmosphere in the classroom. Interaction may help students to improve communicative skills in speaking English and to feel more free and open in the classroom [15].

\section{Objectives}

The aim of this paper is to teach English language with interactive learning facilitates by displaying graphic organizers and role-play games alongside the study of English language, showing the main items of study information and controlling the study material by estimation and assessment methods. As predicted, providing interactive learning on English language lessons improved students' motivation and increased a rate of attendance English classes.

Taking into account low communicative skills in students to acquire English, we tried to apply interactive methods in our medical classes. In this research we taught the first-course medical institute English lessons with students representing various levels of English proficiency.

\section{Materials and Methods}

Interactive learning, in particular graphic organizers and role-play games focus on educative and entertaining aims in the learning process until the students and teacher achieved their personal targets. In this context, we examine how graphic organizers and role-play games support professional English vocabulary learning for medical students. Moreover, medical students need more interesting learning media in English learning to avoid the boredom they experience when taught using conventional methods. The research has been conducted among the first-year students in Tashkent Pediatrician Medical 
Institute and it concludes that the students' competency in the English speaking skills is affected by the internal and external factors, some of which are students' motivation, the level of class atmosphere, the level of English language background and the use of educational teaching interactive learning technologies. Further, sociological survey has researched the requirements of employers (35 respondents of foreign medical organizations participated in the survey) regarding language competence. The result of the experimental English classes with interactive learning for the first course students of the Tashkent Pediatric Medical Institute states that the students' motivation and English class visits increase as they thought the drawing schemes and game are interesting and more knowledgeable.

The sociological survey in the foreign medical organizations, such as pharm companies "Amrita Pharma", "Euromedex", "Medecins sans frontiers, MSF" was presented in paper format in merely the perception of the foreign medical staff of the graduates of the Tashkent Pediatric Medical Institute. It covered the speaking skills and professional linguistic competency of the graduates of the Tashkent Pediatric Medical Institute. First, a set of questionnaire is distributed to 35 foreign medical organizations in Tashkent city. The result of the questionnaire is used as the input of designing interactive learning technologies in teaching English in medical universities. Then, the interactive learning in the form of graphic organizer and role-play game is organized in
English classes for first-year students in the Tashkent Pediatric Medical Institute (28 first-year students). Finally, sociological survey of TashPMI students was conducted, and the students report their perceptions of the content of the course (the sociological survey covered the 1 st and 3 rd year students of TashPMI Pediatrics Department, a total of 100 people). Even though there have been some learning games of English, especially vocabulary, role-play game and graphic organizers in the research are different from the previous ones since they were designed based on the needs of the users, in this case medical students. The summary of the survey of the medical students' needs is: $86 \%$ of the respondents play role-play games in English class; the schemes and graphic diagrams as monitoring of English class are the productive and effective method (69\% of the respondents); three themes in role-play games are the most favorite ones: $19 \%$ choose Gross anatomy, $18 \%$ select Symptoms and diseases, and 13\% like Doctor and Patient dialogues; $66 \%$ of the respondents choose role-play game than conventional methods; $55 \%$ of the respondents prefer to graphic organizers than tests when making teamwork. In summary, the needs of the medical students are: 1) the English classes should have at least one graphic organizer such as Venn's diagram or Fishbone 2) the role-play game should include even some elementary levels to give a chance to involve a whole study group 3) the game uses more medical scientific vocabulary. The following is the difference of the graphic organizers:

Table 1. The characteristics of graphic organizers in English class

\begin{tabular}{|c|c|c|c|c|}
\hline Nam & Venn's diagram & Fishbone & Chamomile & Carousel \\
\hline $\begin{array}{c}\text { Type of work } \\
\text { (team/individual) }\end{array}$ & individual & individual & team & Team \\
\hline Purpose & $\begin{array}{l}\text { To find similarities and differences } \\
\text { of the object }\end{array}$ & $\begin{array}{l}\text { To analyze cause and } \\
\text { effects }\end{array}$ & To cluster object features & Rotating review \\
\hline Achievement & $\begin{array}{l}\text { Quickly and easily find differences } \\
\text { and generalize knowledge about } \\
\text { the chosen topic. This is liked by } \\
\text { both strong and weak students. } \\
\text { This technique is aimed at the } \\
\text { development of the student, whose } \\
\text { main indicators are evaluation, } \\
\text { openness to new ideas, their own } \\
\text { opinion and reflection of their own } \\
\text { judgments. }\end{array}$ & $\begin{array}{l}\text { Students acquire such } \\
\text { meta-subject } \\
\text { competencies as } \\
\text { critical thinking, } \\
\text { interaction in groups, } \\
\text { planning and } \\
\text { implementing research } \\
\text { activities. }\end{array}$ & $\begin{array}{l}\text { This helps to develop the } \\
\text { ability to search, choose, } \\
\text { systematize, analyze and } \\
\text { offer the chosen and } \\
\text { considered decision for the } \\
\text { judgment of your friends, to } \\
\text { defend your opinion and with } \\
\text { the help of your friends, to } \\
\text { find new and interesting } \\
\text { answers. }\end{array}$ & $\begin{array}{l}\text { Using this } \\
\text { technique } \\
\text { brought an } \\
\text { element of } \\
\text { creativity to the } \\
\text { work, increased } \\
\text { interest in the } \\
\text { topics studied. }\end{array}$ \\
\hline
\end{tabular}


Table 2. The characteristics of role-play games in English class

\begin{tabular}{|c|c|c|c|c|}
\hline Nam & Telephone conversation & Body language & Debates & At the doctor \\
\hline $\begin{array}{l}\text { Type of work } \\
\text { (team/pair) }\end{array}$ & pair & Team & team & pair \\
\hline Purpose & $\begin{array}{c}\text { To speak not seeing } \\
\text { partner }\end{array}$ & $\begin{array}{l}\text { To be creative in expressing } \\
\text { new words, widen vocabulary }\end{array}$ & $\begin{array}{c}\text { To use more new } \\
\text { words arguments to } \\
\text { defend }\end{array}$ & $\begin{array}{c}\text { To practice medical } \\
\text { vocabulary in challenging } \\
\text { situations }\end{array}$ \\
\hline Achievement & $\begin{array}{l}\text { Subjective activity of } \\
\text { participants (each } \\
\text { participant of the game } \\
\text { has the opportunity to } \\
\text { show individual } \\
\text { qualities and fix their "I" } \\
\text { not only in the game } \\
\text { situation, but also in the } \\
\text { entire system of } \\
\text { interpersonal relations) }\end{array}$ & $\begin{array}{l}\text { The development of } \\
\text { imagination and creative } \\
\text { abilities of students is } \\
\text { facilitated by the mimicry of } \\
\text { the game situation and the } \\
\text { content of the role-playing } \\
\text { game as a whole, which } \\
\text { occurs due to the clarity of the } \\
\text { model and the implementation } \\
\text { of thoughts in the actions of } \\
\text { players. }\end{array}$ & $\begin{array}{l}\text { A socially significant } \\
\text { type of activity (the } \\
\text { participant, regardless } \\
\text { of the internal structure } \\
\text { and mood, is "obliged" } \\
\text { to play, he cannot help } \\
\text { taking part in the } \\
\text { game, since the } \\
\text { conditions themselves } \\
\text { exclude a passive } \\
\text { position) }\end{array}$ & $\begin{array}{l}\text { Role-playing forms, the ability } \\
\text { of students to play the role of } \\
\text { another person, to see } \\
\text { themselves from the position } \\
\text { of a communication partner. It } \\
\text { focuses students on planning } \\
\text { their own speech behavior and } \\
\text { the behavior of the } \\
\text { interlocutor, develops the } \\
\text { ability to control their actions. }\end{array}$ \\
\hline
\end{tabular}

After entering of teacher, then students entered the classroom; they sat down and worked on a "chamomile' graphic organizer, "hot potato", role games [16]. These informative exercises that gets students to be more active and working in teamwork at the beginning of the lesson. We can use medical topics with Q\&A so that students need to be motivated to study.

After we have discussed any medical topic in interactive way and found some new medical terms to the given theme word or word combination, we did reading of the theme text for about five-ten minutes (this time duration reaped the results we were looking for). Reading is a interactive form of teacher technique, a way to spell new vocabulary, a way to acquire with grammar structures, a way of "no-native language" understanding the text [17].

Before the starting the lesson with students, we explained them about interactive methods and their benefits in learning of English language. We told students that interaction will help them to introduce with each other and get interested in learning process. Interactive learning increases their creative potential and opens their minds to acquire communicative skills. We not only learn English language but also we have self-expression and development of professional skills in role games in our Medical English class. We also described how we would use interactive methods that help them to learn language and control their feedbacks.

There are different types of interactive learning, but we decided to apply graphic-organizer methods and role games with our students because they provided an opportunity for all four skills of English language: speaking, writing, reading, listening.

For each English lesson, we like to use professional medical themes that help students for professional development in learning English language. This focus on theme might be new professional words, a revision of medical words, or students' current medical specialty study. We may choose theme from future specialty of students, for instance neurosurgery, pediatrics, cardiology and so on. Once we decided a theme, students may define it and provide examples of their work experience. Teacher may also give examples of the medical specialty from the hand-out texts and glossary that students will study in the Medical English classroom. For students with upper intermediate degree, teacher may choose famous medical scientists that respective in the future specialty of students. The teacher can apply the professional medical words to students every day, making the interactive learning as main or more interesting method of study in word and word combination learning. The teacher may supply the Medical English class with visual cards or Power Presentation slides to illustrate the professional medical vocabulary.

And the teacher doesn't have to choose only lexical themes in the interactive learning. The teacher can also select a grammar rule according to the curriculum, for example Tenses, Voices and Adjective Comparison Table. It is important, however, to demonstrate some graphic interactive methods such as cluster, KWH table, Venn's circles that help students build construct sentences, motivate students to learn, thus lower lack of confidence and nervous intense [18].

The Sample Interactive Learning in English lesson below give examples of professional lexical and grammar rule specificities; the implementation can be modified for groups of different level. The Glossary is a lexical part of the Medical English Class that provides additional professional words without translation to native language of students.

For organization of the place for the interactive role games, the teacher may play as tutor or supervisor role in the background. There are various professional scenes that can be used in the English lesson for high motivation at the students of first course university. For example, "Doctor and patient", "Taking diagnosis", "Colloquium of doctors" and so on. The teacher can give roles to students and check their professional knowledge in pronunciation, vocabulary experience, grammar rule using in correct way. The students may stay in their seats or sit or move in the class, depending on number of students is needed in the role game scene. 
Once the teacher has set the scene, read the rules of the role game, they controlled the situation, and took results and comments from the viewers (other students).

Sample interactive learning. Before class, the teacher writes the focus word (professional medical theme), with its meaning and word combinations in sentences, on the black or white board:

GP (word combination) - the doctor of General Practice. Clues: graduation, specialization, undergraduate student, vocational studies. GP is level that is given to students after graduation of medical university.

The teacher may also put up pictures of Power Point slides to promote students to apply the word in this or that situations. For mastering and fastening of new study material, such interactive methods can be implemented: chamomile, brain storm, cluster, fish bone. Students actively participate in finding out the words-clues, synonyms, antonyms, guessing the translation of these words.

The debates such as colloquium help students in interaction for activating and enriching vocabulary of professional medicine in English. Divide students in min-groups and give them following questions of the word: Name the medical university in your homeland, the faculties of this university, duration of the course, given specialization degree (GP). Give students a half an hour to focus on their questions and find out additional information to answer these questions.

If the teacher needs to estimate students' knowledge and practical skills in the Medical English Class, the teachers suggest using KWH table, Venn's circles. Also the video presentations or video-scenes with new professional medical terms may be showed by the teacher in Medical English Class.

Word Bank of professional medical word and word combinations is shown as the following.

Table 3. Words and Words combinations

\begin{tabular}{|c|c|c|}
\hline Specialization & Degrees & Human body \\
\hline Ophthalmology & GP & Skeleton \\
\hline Cardiology & Master & Cardiovascular system \\
\hline Pediatrics & PHD & Respiratory system \\
\hline Surgery & MD & Urinary system \\
\hline
\end{tabular}

\section{Results}

A sociological survey conducted with the students of the Tashkent Pediatric Medical Institute revealed that graduates of a non-linguistic medical university do not meet the requirements of employers (35 respondents of foreign medical organizations participated in the survey) regarding language competence. Where there is an insufficient number of students' practice $(25 \%)$ and poor communication skills of students from the real work of modern organizations (23\%). According to employers, specialists of international medical organizations should participate in the organization of the educational process of the university, in particular, in holding joint seminars for future staff $(27 \%)$. (see Figure 1.).

\section{Why, do you think that the knowledge and skills that students receive today at the university do not meet your requirements (expectations)?}

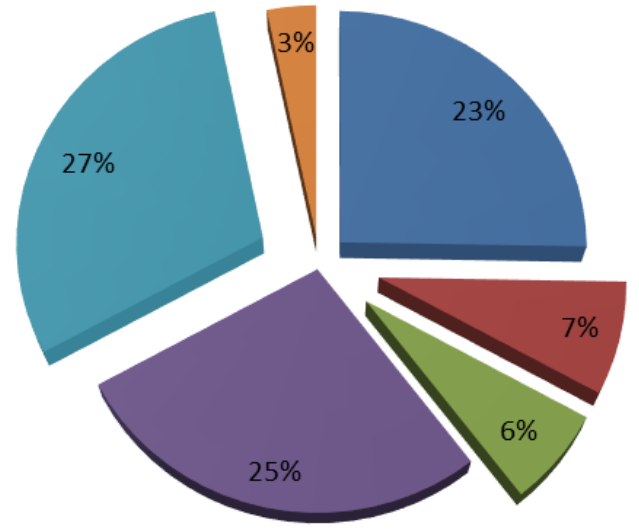

Poor knowledge acquired by young professionals

- Teachers have no practical experience

Weak language training

Not enough practice related to the specifics of the future profession.

- The training process does not involve specialists from employers' organizations.

Your answer choice

Figure 1. A sociological survey with medical organizations and students of TashPMI 
The role-play game and graphic organizers for experimental English classes for the first-year students in the Tashkent Pediatric Medical Institute consist of three themes (Gross Anatomy, Symptoms and Diseases, Doctor and Patient). Each of them starts with knowledge of specific theme. The students are given some time to learn the knowledge before they apply the knowledge in the game. This way allows students to understand the new vocabulary so that they can use it in the role-play game or graphic organizer. Students can choose the partner or to organize team and participate within limited amount of time. Teacher can repeat the game to find out if there is progress noting the record for the next lesson. The following is the sample of graphic organizer as interactive vocabulary game - that is the knowledge of Disease of Digestive System. Fig 2 shows circles of the Venn's diagram where the students have analyzed the similar and different symptoms of Digestive System diseases (A Stomach Cancer, B- Gastritis, C- Cholecystitis, DAppendicitis). This part provides students with the information to guide them in learning the English vocabulary.

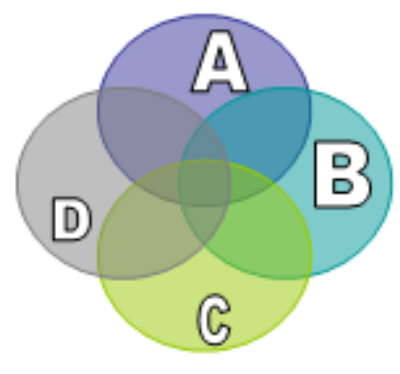

Figure 2. Venn's Diagram on Digestive System Diseases

The perception of the graphic organizer Venn's diagram by students is based on the result of the questionnaire filled in the table 4. Indicators of Venn's Diagram in English Medical Class

Table 4. Indicators of Venn's Diagram in English Medical Class

\begin{tabular}{|c|c|c|}
\hline No. & Key indicator & Percentage \\
\hline 1 & $\begin{array}{c}\text { Students evaluation of the graphic organizer } \\
\text { Venn's diagram }\end{array}$ & $83 \%$ \\
\hline 2 & $\begin{array}{c}\text { Interesting way of learning English medical } \\
\text { terms }\end{array}$ & $90 \%$ \\
\hline 3 & $\begin{array}{c}\text { To increase motivation to study boring } \\
\text { medical terms }\end{array}$ & $80 \%$ \\
\hline 4 & To encourage partner and team work & $86 \%$ \\
\hline 5 & $\begin{array}{c}\text { Recommended to be included in English } \\
\text { classes }\end{array}$ & $83 \%$ \\
\hline
\end{tabular}

\section{Discussion}

For young people entering vocational education, the problem of language competence has not been definitively solved. Some of them are disappointed already in the first year of study, others - at the beginning of independent professional activity, third - after 3-5 years of work in the profession.
The doctor's specialty, which meets the modern requirements of professionalism, is characterized by a high degree of autonomy and communicativeness, which is manifested, along with a high level of professional competence, in such "business qualities" as flexibility of professional thinking, mobility and adaptability to innovative situations of professional activity, continuous professional self-improvement, ability to work in a team, to cooperate with others, to take the initiative and responsibility. Naturally, it can be assumed that these characteristics and qualities are the subject of professional training in the conditions of formal university education. However, in the current socio-cultural situation in higher education, at best, two paradigms coexist - traditional and innovative, which is not effective enough in fulfilling the social order of society education [19].

At the present stage, an undoubted obstacle to the progressive movement of the education system is the existence of a huge army of professional foreign language teachers, who have absolutely no knowledge of competencies within the framework of European requirements.

The Council of Europe sets out five basic competencies that any professional needs today. In the context of the training of foreign language teachers, they take on particular importance.

1. Political and social competences related to the ability to take responsibility, to participate in joint decision-making, to participate in the functioning and development of democratic institutions.

2. Competences related to living in a multicultural society, designed to discourage the emergence of xenophobia and the spread of a climate of intolerance and to promote both understanding of differences and a willingness to live with people of other cultures, languages and religions.

3. Competence to master oral and written communication important in work and public life to such an extent that those who do not master it are at risk of isolation from society. This group of communication includes mastery of several languages, which is becoming increasingly important.

4. Competences related to the emergence of an information society. Possession of new technologies, understanding of their strength and weakness, ability to be critical of information and advertising disseminated through the media and Internet.

5. Competencies that realize the ability and desire to learn throughout life, not only professionally, but also in personal and public life.

Thus, the analysis of these approaches to the concept of foreign-language communication competence shows that all scientists agree on the presence in foreign-language education of such components as linguistic and socio-cultural knowledge, speech, sociolinguistic and socio-cultural skills [20,21].

The course of medical English for medical specialists at TashPMI is designed for 3 years, for a total of 500-1000 students, and on average $80-90 \%$ of them successfully 
complete this course. According to the sociological survey of TashPMI students, the students report that the content of the course is useful and relevant to the clinics (72\%), and $52 \%$ believe that medical English should be a mandatory course (the sociological survey covered the 1st and 3rd year students of TashPMI Pediatrics Department, a total of 100 people). The students conduct seminars on medical English vocabulary and conversation skills under the guidance of teachers as a preparatory step in the first and second courses of TashPMI. This initial impact helps many students to determine for themselves the need to improve their basic English language skills before being selected for a TashPMI Master's degree, for which an intermediate requirement in English is met. The formal elective plan is designed for 3 years of official credit, in which students conduct a 1-hour daily practical lesson per week, but have multiple components of self-study multimedia and grammar/lexical exercises, a series of sample dialogues for patient interviews, objective structured clinical examinations with video materials, and scientific and medical research distributed during the 3rd year. The course topics are based on human anatomy (musculoskeletal, pulmonary, cardiovascular, gastrointestinal, endocrine, genitourinary, ophthalmologic, auricular, nasal and throat, neurological, psychiatric and pediatric), each week focusing on one topic and addressing class role-playing games, interviewing patients, writing cases, as well as developing appropriate materials for patient training. In future, it is expected that in the 3 rd year students will combine medical English with other clinical subjects.

Based on the above, the following definition of the language competence of medical graduates can be given: it is a system of linguistic, sociolinguistic, cultural, strategic and discursive knowledge, skills and abilities that allow communicators to interact effectively in specific socially deterministic communicative situations, as well as the knowledge and ability to apply available knowledge in practical and scientific medicine.

The necessity of further deepening the issue of developing the system of language competencies of medical students, the need for pedagogical justification of new approaches and directions of language training of future doctors in the conditions of profiling the primary level of higher education require additional research.

\section{Conclusions}

Interactive learning in Medical English class helped students in our institute in particular Tashkent Pediatric Medical Institute to be more motivated and interested in professional language study. The techniques that suggested here can be applied for the first-year students without academic approach and for any backstage. I

Thus, the basis for the formation of a new generation of specialist was the change in the content of higher professional education, which provides its fundamentalization, humanization, humanization and differentiation, as well as the development and implementation of innovative pedagogical technologies.

It became clear that there was a need for a radical change in the nature of training future medical personnel, their language and communication training, which is designed to develop professional thinking among students, to form language skills and abilities that ensure their readiness to work in international medical centers, to participate in foreign scientific and practical activities of medical institutions (based on what results of a sociological survey of employers of international medical organizations and students of TashPMI). And in the same way, it is easy to take English by ear, also to communicate with colleagues from other countries. The doctor must speak English clearly so that the other person can understand every word he or she says, including medical terms that are difficult to pronounce... After analyzing all the above points, it can be concluded that English is very important in medicine. It is a language that connects knowledge and achievements from different countries, allows you to transfer and learn from experience, skills and knowledge. Nowadays, it is no secret that every doctor should know medical English.

This study is an attempt to study the problem of language competence formation in medical students. The need for such a study is due to an insufficient level of language knowledge and language and speech skills, the lack of practical methodological guidelines for forming language competence in medicine, the increased requirements for professional training of a physician. In the course of the study, the theoretical problems of forming language competence as a fundamental component of communicative competence were revealed.

The study of this problem has shown that the following approaches should be taken into account to determine the methods of language competence formation in medical students: professional, linguistic and country linguistics communicative, sociocultural.

The analysis of the results of our sociological survey of employers of international medical organizations and TashPMI students allowed us to determine the motives of employers and students, their goals in the study of foreign language, the awareness of the role of foreign language in professional information and professional communication. These data have influenced the solution to the problem of goal-setting and content selection for the formation of language competence.

The prospects for this study include the possibility of further developing the problem of teaching non-linguistic university students, particularly medical students, in the process of forming professional competencies, and organizing joint seminars and training sessions with foreign specialists and foreign employers in the medical field.

\section{Acknowledgements}

We are very grateful to experts for their appropriate and 
constructive suggestions to improve this paper.

\section{REFERENCES}

[1] T.S. Panina, L.N. Vavilova, Modern methods of activization of training, Handbook for students, ed. by T.S. Panina, 4th ed., Moscow, 2008.

[2] tashpmi.uz/en/education/faculties/first_facult_ped...og_psy hol/o_kafedri/English for medical students: The text-book for students, post-graduates and scientific staff. - M.: Flinta6 Nauka2000. - 384 p.

[3] R.Blair, Innovation approaches to language teaching, New York, Newbury House, 2010.

[4] S.Martinelli, M.Tailor, Intercultural Learning, Strasbourg, Council of Europe and European Commission, 2000.

[5] H.Stern, Fundamental Concepts of Language Teaching, Oxford, Oxford University Press, 1983.

[6] E.S. Polat, New pedagogical and information technology in education, Tutorial for students of pedagogical colleges, Moscow, Publishing center «Academy», 2000.

[7] Warschauer, M., \& Meskill, C. (2000). Technology and second language learning.

[8] Salaberry, M. (2001). The use of technology for second language learning and teaching: A retrospective. The Modern Language Journal, 85(1), 41-56.https://doi.org/10.1111/0026-7902.00096

[9] Darch, C., \& Eaves, R. (1986). Visual displays to increase comprehension in high school learning disabled students. Journal of Special Education, 20(3), 309-31

[10] Marzano, R., Pickering, D., \& Pollock, J. (2001). Research-based strategies for increasing student achievement. Classroom instruction that works. Alexandria, VA: Association for Supervision and Curriculum Development

[11] A.M. Maslova, Z.I. Wainstein, L.S. Plebeyskaya Essential English for medical high schools .Moscow: List-New, 2002.

[12] Scale Up: The student's book for students of high schools. T.:UzSWLU 2014. -81 p.

[13] L.U.Khojayeva L.U., Arziyeva D.T. Ingliztili: The text-book for medical high schools.- T.:Davlatilmiynashriyoti, 2005. $-200 p$.

[14] Krashen, S. 1982. Principles and practice in second language acquisition. Oxford: Pergamon Press/

[15] Machado, A.2014. Should school teach kids to mediate? The Atlantic (January 27).www.theatlantic.com/education/arch ive/2014/01/should-school-teach-kids-to-meditate/283229

[16] Yudintseva, A. 2015. Game-enhanced second language vocabulary acquisition strategies: A systematic review. Open Journal of Social Sciences, 3, 101-109. https:// doi.o $\mathrm{rg} / 10.4236 /$ jss.2015.310015

[17] Ronald C.Doll Curriculum Improvement: Decision Making. Boston.:Allyn and Bacon Inc. - 465 p.

[18] Campbell, E. 2013. Research round-up: Mindfulness in schools. Greater Good (October 10). Greatergood.berkeley .edu/article/item/research_round_up_school_based_mindfu lness_programms

[19] Lebedinsky M. S, Myasishev V. N. Introduction to medical psychology. L.: Copper, 1966., p.79.

[20] Directive 2005/36/EC on the recognition of professional qualifications, now amended as Directive 2013/55/EU.

[21] Davies H. Competence-Based Curricula in the Context of Bologna and EU Higher Education Policy. Pharmacy (Basel). 2017;5(2):17. Published 2017 Mar 26.doi:10.3390 /pharmacy5020017 